Editorials

17 Mesenterial Ischemia and Vascular Disorders Klar, E. (Rostock), Eckstein, H.-H. (München); Hauenstein, K. (Rostock)

269 Visceral Surgery - quo vadis Chirurgische GASTROENTEROLOGIE INTERDISZIPLINÄR? Bittner, R. (Stuttgart)

3117 Chronic Wounds and the Relevance of Their Treatment

Köveker, G. (Sindelfingen); Debus, E.S. (Hamburg)

4218 Center Formation in Gastrointestinal Surgery Klar, E. (Rostock); Siewert, J. (München)

Main Topic

Mesenterial Ischemia and Vascular Disorders

Editors: E. Klar, Rostock; H.-H. Eckstein, München;

K. Hauenstein, Rostock

18 Acute Mesenterial Ischemia - Etiology and Risk Factors Lock, G. (Hamburg)

113 Radiologic Diagnostics in Acute Mesenterial Ischemia: Time Saving and Reliability Müller-Hülsbeck, S. (Kiel)

117 Acute Mesenterial Ischemia: Management and Radiological Interventions in the Treatment of Acute Arterial Occlusion and Venous Thrombosis Kröger, J.-C.; Hauenstein, K. (Rostock)

125 Surgical Concept in Acute Mesenteric Ischemia Schneider, C.G.; Zehler, O. (Hamburg); Kastl, S. (Ulm); Izbicki, J.R. (Hamburg)

129 Nonocclusive Mesenteric Ischemia - Diagnosis and Therapy by Vascular Surgical Treatment Luther, B. (Krefeld)

136 Chronic Mesenteric Ischemia - Surgical and Interventional Options in Therapy Wolf, O.; Heider, P.; Heinz; M.; Weiss, W.; Berger, H.; Eckstein, H.-H. (München)

\section{Wound Healing}

Editors: G. Köveker, Sindelfingen; E.S. Debus, Hamburg

3119 The Diabetic Foot: Diagnosis and Interdisciplinary Management

Morbach, S. (Soest)

3127 Infections of Chronical Wounds: The Diabetic Foot Systemic and Local Treatment Options Diener, H.; Wintzer, H.; Daum, H.; Debus, E.S. (Hamburg)

3138 Digital Documentation of the Treatment of Chronic Wounds: What Is Important?

Riediger, H.; Moosmann, C.; Hopt, U.T.; Pfeffer, F. (Freiburg i.Br.)

3143 Diagnosis and Therapeutic Options in Chronic Venous Ulcers

Noppeney, T. (Nürnberg)

3147 Wound Dressings: Overview and Classification Horn, T. (Krefeld)

3155 Update on Plastic Surgical Management of Pressure Sores

Hierner, R.; Flour, M. (Leuven); Notebaert, M. (Melsbroeck); Tombeur, M.; Kiekens, C.; Degreef, H.; Veckman, L.;

Vandermersch, E.; Joosten, E. (Leuven)

3169 Gene Therapy with Growth Factor Genes A New Therapeutic Approach for Acute and Chronic Wounds? Branski, L.K.; Herndon, D.N.; Jeschke, M.G. (Galveston, TX)

\section{Center Formation in Hospitals}

Editors: E. Klar, Rostock; J. Siewert, München

\section{The Hepatologic Center Mainz}

Otto, G.; Schuchmann, M.; Ties, J.; Weinmann, A.; Mönch, C.; Galle, P. (Mainz)

4224 Pelvic Floor Centre Farke, S.; Roblick, U.J.; Bruch, H.P. (Lübeck)

4230 Modern Organization of Medical Centers, Why Center Formation? - the Example of the University Medical Center Hamburg-Eppendorf Schmitz, C.; Quante, S.; Debatin, J.F. (Hamburg)

\section{The National Center for Tumor Diseases} Heidelberg Weitz, J.; Beiglböck, A.; Kienle, P.; von Kalle, C.; Jäger, D.; Büchler, M.W. (Heidelberg) 
4242 Accompanying Conditions for Center Formation: Requirements Concerning Modern Quality Management Systems Dahmen, K. (Rostock)

4247 The Medizinisches Versorgungszentrum (MVZ) as an Affiliate of a Teaching Hospital - Experience after 1 Year MVZ Leverkusen gGmbH Weiß, A. (Leverkusen)

4251 URIG: Characteristics of the Interdisciplinary Vascular Center of the University of Rostock Schareck, W.; Bünger, C.; Nienaber, C.; Hofmockel, R.; Liebold, A.; Kroeger, J.C.; Rolfs, A. (Rostock)

4256 Breast Cancer Center Grosse, R.; Thomssen, C. (Halle/Saale)

Interdisciplinary Discussions

142 Mesenterial Ischemia / Vascular Disorders Eckstein, H.-H. (München (Moderator))

3175 Wound Treatment in Germany Coerper, S. (Tübingen)

4260 Center Formation in Gastrointestinal Surgery Schilling, M. (Homburg/Saar); Klar, E. (Rostock) - Discussion Leaders)

Original Articles

147 One-Stage Operation for Cancer of the Left Colon with Bowel Obstruction: Do We Need On-Table WashOut of the Colon?

Poskus, E.; Jotautas, V.; Zeromskas, P.; Stratilatovas, E.; Stasinskas, A.; Strupas, K. (Vilnius)

273 Biliary Complications after Liver

Transplantation

Lin, C.-H. (Taipei); Chen, T.-W. (Taipei); Chou, S.J. (Taipei Hsien); Hsieh, H.-F. (Taoyuan); Chu, H.-C.; Yu, J.-C.; Liu, Y.-C.; Hsieh, C.-B. (Taipei)

279 Effects of $\mathrm{CO}_{2}$ Pneumoperitoneum on Nephrotoxicity of Sevoflurane: An Experimental Study in Rabbits

Bayar, M. S.; Küçükgüçlü, S.; Gokmen, N.; Dursun, Z.; Tuna, E.B.; Erkan, N. (Izmir)

3179 Prognostic Factors of Retroperitoneal Soft-Tissue Sarcomas

Derici, H.; Tansug, T.; Nazli, O.; Bozdag, A.D.; Reyhan, E.; Kara, C. (Izmir)

3185 The Effects of Various Scolicidal Agents on the Hepatopancreatic Biliary System Topcu, O.; Aydin, C.; Arici, S.; Duman, M.; Koyuncu, A.; Sen, M. (Sivas)
4265 Hepaticojejunostomy or Cholecystojejunostomy for Palliation of Obstructive Jaundice in Periampullary Tumors?

Tarcan, E.; Gür, S.; Atahan, K.; Surat, H.; Taskin, B.; Durak, E.; Cökmez, A. (Izmir)

4269 Gum Chewing in Patients with Subtotal Gastrectomy

Chou, S.-J.; Lin, C.-H. (Taipei); Hsieh, H.-F. (Taoyuan); Yu, J.-C; Chen, T.-W.; Chan, D.-C. (Taipei)

Case Reports

152 An Uneventful Complication of Behçet's Disease: Intestinal Perforation Yildirim, M.; Erkan, N.; Bayam, E.; Sahin, T. (Izmir)

155 Rectorectal Dermoid Cyst

Erkan, N.; Agdeniz, S.; Polat, A.F.; Yildirim, M. (Izmir)

158 Cervical Spine Metastasis as a Primary Manifestation of Occult Colorectal Carcinoma: Case Report Huang, T.-W.; Ou, J.-J.; Lai, H.-J;; Tsai, W.-C.; Jao, S.-W.; Chao, P.-C. (Taipei)

285 Hepatic Angiomyolipoma: A Rare Case Report and Review of the Literature

Hsu, S.-D. (Taipei); Hsieh, H.-F. (Taoyuan); Chao, S.-J. (Taipei Hsien); Yu, J.-C.; Peng, Y.-J;; Lin, C.-H.; Liu, Y.-C. (Taipei)

288 Adenosquamous Carcinoma of the Common Bile Duct with Choledochoduodenal Fistula Chen, S.-Y.; Lin, C.-H.; Yu, J.-C.; Liu, Y.-C. (Taipei)

292 Small Bowel Perforation Secondary to Metastatic Lung Cancer: A Case Report with Literature Review Huang, T.-W.; Wang, C.-H.; Tsai, W.-C.; Liu, Y.-C. (Taipei)

295 Inflammatory Pseudotumor of the Liver following Streptococcus bovis Liver Abscess and Occult Colonic Cancer

Chuang, C.-H. (Taipei); Chou, S.-J. (Taipei Hsien); Yu, J.-C.; Chang, T.-M.; Gao, H.-W.; Chao, P.-C.; Lin, C.-H.; Hsieh, C.-B. (Taipei)

298 Adult Hirschsprung's Disease: A Case Report Hsieh, H.-F. (Taoyuan); Lin, C.-H.; Hsu, S.-D.; Peng, Y.-J.; Chan, D.-C.; Chuang, C.-H.; Yu, J.-.C. (Taipei)

2101 Duodenojejunal Anastomosis with Proximal Jejunostomy in the Treatment of Duodenal Necrosis Olakowski, M.; Lesieka, M; Handzlik, R.; Lampe, P. (Katowice)

3191 Blunt Abdominal Injury with Transection of Pancreatic Neck Detected Early by Abdominal Computed Tomography: A Case Report and Review of Literature Wang, C.H.; Hsu, S.D.; Huang, T.W; Liu, Y-C (Taipei)

3195 Testicular Choriocarcinoma with Jejunal Metastasis Complicated by Intestinal Perforation and Acute Peritonitis

Veselý, P.; Flip, S.; Vaculíkova, M.; Odráæka, K.; Jon, B.; Nikolov, D.H. Jansa, J.; Melichar, B. (Hradec Králové) 
3198 Gastrointestinal Stromal Tumor of the Remnant Stomach

Erkan, N.; Sahin, T.; Coskun, A.; Alev, M.; Agdeniz, S.; Postacı, H. (Izmir)

3201 Salmonella Splenic Abscess as an Unusual Complication of Acute Gastroenteritis Chen, S.-Y.; Hsu, S.-D.; Yu, J.-C.; Yu, C.-P.; Yu, C.-Y.; Lin, C.-H.; Liu, Y.-C. (Taipei)

4272 Gallbladder Blunt Trauma: Unusual Presentation and Difficult Diagnosis

Di Carlo, I.; Sparatore, F.; Primo, S.; Toro, A. (Catania)

4275 Interdisciplinary Treatment of Bilobular Caroli's Syndrome by Side-To-Side Choledochoduodenostomy and Subsequent Endoscopic Stone Removal Gäbelein, G.; Glanemann, M.; Adler, A.; Neuhaus, P.; Hintze, R.E. (Berlin)

4278 Malignant Melanoma of the Anorectum Glanemann, M.; Morgott, F.; Noske, A.; Spinelli, A.; Neuhaus, P. (Berlin)

4273 Pseudomyxoma peritonei Manifesting as Umbilical Hernia: Report of a Case and Review of the Literature Hsu, S.-D. (Taipei); Hsieh, H.-F. (Taoyuang); Lin, C.-H.; Chan, D.-C.; Peng, Y.-J.; Liu, Y.-C. (Taipei)

Book Reviews

2 104, 3 204, 4287

Innovations

\section{1}

News / Ticker

161,4292

Meetings and Conferences

$\mathbf{1}$ 62, 2 109, 3210,4294

4298 Author Index Vol. 22, 2006

4300 Subject Index Vol. 22, 2006

\section{Supplement 1}

Viszeralmedizin - State of the Art

Editors: R. Bittner, Stuttgart; W. Kruis, Köln

ISBN 10: 3-8055-8257-0 / ISBN 13: 978-3-8055-8257-5

Editorial

V On the Way to Visceral Medicine

Bittner, R. (Stuttgart); Kruis, W. (Köln)

Review Articles

1 Extent of Resection and Conception of Treatment in Patients with Hereditary Nonpolyposis Colorectal Cancer - Index Patient: Surgical Strategy Pistorius, S. (Dresden)

6 Interdisciplinary Sonography in the Acute Abdomen Gastroenterological Perspective Schacherer, D.; Schlottmann, K. (Regensburg)

15 Management of Sigmoid Diverticulitis from a Surgical View

Junghans, T.; Schwenk, W. (Berlin)

21 Chronic Pancreatitis and Pain - Surgical View Müller, S.A.; Welsch, T.; Kleeff, J.; Schmied, B.M.; Büchler, M.W.; Friess, H.; Schmidt, J. (Heidelberg)

27 Sonography in Acute Abdomen from the Surgical Point of View Zielke, A. (Offenbach)

33 Indication for Surgical Therapy of Sigmadiverticulitis Seen from the View of the Gastroenterologist Damian, U.; Riemann, J.F. (Ludwigshafen)

Type of Resection and Concept of Treatment in Index Patients with Hereditary Non-Polypous Colorectal Carcinoma - Gastroenterologist's View Andus, T. (Stuttgart)

43 Gastro-Oesophageal Reflux Disease - Really an Interdisciplinary Disease?

Koop, H. (Berlin)

48 Gallbladder Stones - a Change in the Interdisciplinary Approach?

Pusl, T.; Hüttl, T.P.; Beuers, U. (München)

53 Interdisciplinary Approach to the Treatment of Stenosis and Fistulae in Crohn's Disease Hoffmann, J.C. (Berlin)

60 Chronic Pancreatitis and Pain - an Interdisciplinary Challenge

Rünzi, M.; Rehbehn, K.-U. (Essen) 